\title{
Thesis Statement: A Vital Element in Expository Essays
}

\author{
Edward Owusu (Corresponding author) \\ Department of Liberal and General Studies, Sunyani Polytechnic, Sunyani, Ghana \\ Asuamah Adade-Yeboah \\ Department of Communication Studies, Christian Service University College, Kumasi, Ghana
}

\begin{abstract}
The thesis statement is an essential component of the introductory section of every essay. In a classroom situation, most students see its construction as challenging; others on the other hand are completely oblivious of it and the vital role it plays in essay writing. The study therefore examines the essence of using a Thesis Statement in expository essays. The design of the study is largely influenced by the works of Langan (2001), Samuels (2004), Lane (2004) Tagg (2004) Johnson (2004) and Felts (2006). Literature was mainly reviewed on the definition of the thesis statement, mistakes on the construction of thesis statements and how to write captivating thesis statements. The participants who provided the primary data were drawn from students of two prominent private universities in Kumasi, Ghana (Christian Service and Ghana Baptist University Colleges). The study brought to light that the participants have challenges constructing theses in their essays. It is therefore recommended that the players in the field of Second Language teaching and learning - teachers, learners, textbook writers, and policy makers - should give maximum attention to this issue whenever the subject matter - essay writing - is being taught, learnt or mentioned.
\end{abstract}

Index Terms - thesis statement, essay writing, methods of development

\section{INTRODUCTION}

It is common knowledge that an essay should have an introduction, which is the opening of the write-up; a body, which deals with the content to be expatiated on; and a conclusion, which closes or summarises the whole write-up. In line with this, Langan (2001, p.11) has also put forward a diagram (known as one-three-one) that shows at a glance the different parts of a standard college essay as follows:

Intr oduction \begin{tabular}{|l|} 
Title of the Essay \\
$\qquad \begin{array}{l}\text { Opening remarks to catch } \\
\text { reader's interest; Thes is } \\
\text { statement; Plan of } \\
\text { development (optional) }\end{array}$ \\
$\qquad$\begin{tabular}{l}
\hline $\begin{array}{l}\text { Topic Sentence 1 } \\
\text { (supporting point 1) } \\
\text { Specific evidence }\end{array}$ \\
Body $\begin{array}{l}\text { Topic Sentence 2 } \\
\text { (supporting point 2) } \\
\text { Specific evidence }\end{array}$ \\
Conclusion \\
Fopic Sentence 3 \\
(supporting point 3) \\
Specific evidence
\end{tabular} \\
\hline $\begin{array}{l}\text { Summary (optional) } \\
\text { General closing remarks } \\
\text { (or both) }\end{array}$ \\
Source: Adapted from Langan (2001, p.11) \\
The One-Three-One Essay
\end{tabular}

The diagram according to Langan (2001) is the traditional form of the essay. Thus, an essay should have an introduction which should have a hook (catchy opening remarks such as: I wouldn't want to be a teenager again ... (p. 60), and I recently read about an area of the former Soviet Union where many people live to be well over a hundred 
years old. ... (p.62)). These sentences have the propensity of attracting the reader's attention. An essay should also have a thesis statement; and an optional plan of development. Some writers (for example, Abrams, 2000; and Lane, 2004) in the field of essay writing have also suggested ideas on the structure or parts of the essay. Abrams (2000) proposes that in addition to the traditional parts (introduction, body and conclusion); an essay should have a thesis. Lane (2004) opines that a good essay should have the following structure or format:

\section{Topic/Title}

\section{Intr oduction of Ess ay}

A. Write a few sentences that lead into the main point of your essay

B. End your first paragraph with your thesis statement

(3 main points you are going to support)

1. First point in thesis

2. Second point in thesis

3. Third point in thesis

III. Body of Essay

A. Topic One - First Point in Thesis

1. Support your point with either quotations or solid evidence

2. Have at least five sentences

B. Topic Two-Second Point in Thesis

1. Support your point with either quotations or solid evidence

2. Have at least five sentences

C. Topic Three - Third Point in Thesis

1. Support your point with either quotations or solid evidence

2. Have at least five sentences

\section{V. Conclusion}

A. Write a few sentences summarising your essay

B. Restate your thesis and how you proved your point

Figure 2: Format for Writing Good Essays

Source: Adapted from Lane (2004)

Taking a closer look at Lane's outline, one realizes that a number of issues are mentioned in the Introduction of an Essay. These are: sentences that lead into the main point of the essay; thesis statement; first point in thesis; second point in thesis and; third point in thesis.

According to Hoy II (1992): ... the introduction of an essay ends with a thesis statement that represents the writer's conclusion about the controversial issue being discussed. The body of the essay defends that thesis in an objective, logical way (Hoy II, 1992, p.7). The conclusion usually begins with a reminder of the writer's thesis and ends with a meaningful generalization about the essay (Hoy II, 1992, p.7). This paper therefore focuses on the composition of thesis statement and its dos and don'ts.

\section{LITERATURE REVIEW}

\section{A. Thesis Statement Defined}

According to Tagg (2004): "A thesis statement is a single declarative sentence that states what you want your readers to know, believe, or understand after having read your essay." Tagg (2004, section 1.4.1) thus, believes that a thesis statement should be made up of just one sentence, and not two or more. Again, it should be in a declarative sentence form, and not in an interrogative, imperative or exclamatory sentence form.

Jerz (2011) also argues that a thesis statement is the single, specific claim that one's essay supports. It is a statement that answers the question one wants to raise; it does so by presenting a topic, the writer's precise opinion on the topic, and a reasoning blueprint that sketches out the organisation for the rest of the paper. An example is illustrated below:

Because the events in the story emphasize Black Elk's role as a Sioux Warrior, and do not describe his eventual conversion to Catholicism and membership in the Society of St. Joseph, 'Black Elk Speaks' presents a skewed and simplified view of the complex history of Native Americans (Jerz, 2011).

Thus, a good thesis is not merely a factual statement, an observation, a personal opinion or preference, or the question one plans to answer but a statement that corroborates one's essay. Jerz's (2011) idea is in consonance with Tagg's (2004) conceptualisation of a thesis statement as "a single declarative sentence..."

Samuel (2004) for his part believes that a thesis statement should be the product of one's own critical thinking after one has done some research. It can, thus, be thought of as the angle or point of view from which one wants to present one's material (Samuels, 2004). This means that two or more different writers can develop diverse thesis statements from the same topic depending on their perception of the subject matter.

To Carroll et al. (2001, p. 787), it is a statement of an essay's main idea; all information in the essay supports or elaborates this idea. Thus, a thesis statement is the pivot around which all other sentences in one's essay revolve. So, every sentence being it simple, compound, complex or compound-complex should aim at substantiating the thesis 
statement. "Usually, the thesis statement is followed by a few sentences that outline how you will make your key point" (Carroll et. al, 2001, p. 39). An example is illustrated below:

Thesis: A honeymoon is perhaps the worst way to begin a marriage... (Langan, 2001, p.52)

Other sentence But, most newly-weds believe that marriage life cannot begin without a honeymoon.

\section{B. Mistakes to Avoid When Writing a Thesis Statement}

Writing a thesis statement could pose problems for most writers if they are unaware of the elements to avoid in composing a good thesis statement. Langan (2001:53) argues that most people make the following mistakes when composing a thesis:

- Announcements of subject rather than stating a true thesis idea

- Composing of statements that are too broad and wordy

- Writing statements that are too narrow

(Langan 2001, p.53)

Although a thesis is a statement that announces the opinion of a writer, its composition could be wrongly framed if the writer announces the subject rather than state a debatable idea. Langan (2001, p.53) thus, cites the following as instances where a thesis announces the subject instead of stating an idea: The subject of this paper will be my parents, and I want to talk about the crime wave in our country (Langan 2001, p.53). The two examples do not make a point about parents and crime but rather tell, in a weak and unimaginative way, the writer's general subject (Langan 2001, p.54). Thus, the use of personal pronouns especially "I" in the second instance stated above and by inference "We" in most theses, make thesis statements sound more of an announcement than an expression of idea.

Furthermore, Langan (2001) reasons that composition of a thesis should neither be too broad nor limited. This means that a thesis should not have too many words or too few words. His assertion, however, has the inclination of confusing writers and students since most of them (writers and students) are likely to ask questions such as to what level will my thesis be considered too broad or narrow?, How many words should my thesis have? An obvious answer could be, compound-complex sentences are too wordy and should not be used in couching a thesis of an essay; and a thesis like Social Security and Old Age (www.leo.stcloudstate.edu) is too limited, short and talks only about the title of the essay hence, it cannot constitute a thesis. However, issues of 'wordy' and 'narrow' are more about style. This does not mean they are not important; of course they are, but the main issue seems to be more about ensuring that one's thesis has a point to make - and a writer can make a point using few words or many works.

Felts (2006) also thinks that a thesis is not a fact, but is an assertion about facts. This statement sounds punning and paradoxical; but it makes sense. What Felts (2006) wants to put across is that a thesis should not necessarily be an accurate issue; but rather a claim which holds water. A thesis statement is an assertion, not a statement of fact or an observation (www.leo.stcloudstate.edu). For example, a statement like People use many lawn chemicals which could be a factual issue or an observation could be reframed: People are poisoning the environment with chemicals merely to keep their lawns clean (www.leo.stcloudstate.edu). This statement constitutes a good thesis in that it is a claim which can be substantiated in the body of the essay.

According to Tagg (2004) it is mistaken for a thesis to be worded in the negative statement. Thus, the negator - not should be absent in the construction of a thesis. One therefore should state what somebody did, not what they didn't do; what caused the problem, not what didn't cause it; what one knows, not what one doesn't know. When the thesis is framed in the negative sense, it makes it difficult for auxiliary statements to be raised in support of the thesis. An example is: it is a terrible time to be an adult.

\section{Writing Captivating Thesis Statements}

There are some factors or methods that one has to consider or use when one desires to write a winning thesis. If broad, wordy, general, factual and purposeful statements are to be avoided when composing a thesis, the question then is: "What are the variables that one should consider in composing a good thesis?" The first factor to consider before composing a thesis is the statement of purpose. The thesis statement of a write up can be developed only after the statement of purpose has been clearly written (Samuels, 2004). The statement of purpose answers the questions "why?" and "how?" Hence, without writing it, it becomes intricate for one to compose a thesis statement. The table below juxtaposes statement of purpose and possible thesis statement: 
TABLE 1

STATEMENT OF PURPOSE AS AGAINST POSSIBLE THESIS STATEMENT

\begin{tabular}{|ll|}
\hline STATEMENT OF PURPOSE & POSSIBLE THESIS STATEMENT \\
\hline $\begin{array}{l}\text { 1. "I want to learn about what has influenced the } \\
\text { music of Daddy Lumba }\end{array}$ & $\begin{array}{l}\text { 1. The music of Daddy Lumba has been heavily } \\
\text { influenced by the 21st century youth in Ghana. }\end{array}$ \\
\hline $\begin{array}{l}\text { 2. "I want to write about how the 'Azonto } \\
\text { Dance } 2 \text { has influenced Ghanaians of today." }\end{array}$ & $\begin{array}{l}\text { 2. In recent times, the "Azonto Dance" has heavily } \\
\text { influenced the lives of people in Ghana. }\end{array}$ \\
\hline $\begin{array}{l}\text { 3. "I want to write on how to learn to make one's } \\
\text { own clothes." }\end{array}$ & $\begin{array}{l}\text { 3. Learning to make your own clothes is easy, fun, and, } \\
\text { best of all, inexpensive (Forlini } \text { et. al, 1987, p.517) }\end{array}$ \\
\hline $\begin{array}{l}\text { 4. "I want to write on Lionel Messi - the star } \\
\text { player of FC Barcelona." }\end{array}$ & $\begin{array}{l}\text { 4. FC Barcelona's Lionel Messi is without doubt the most } \\
\text { skillful player on planet - earth. }\end{array}$ \\
\hline
\end{tabular}

From Table 1 above, one can apprehend that the statement of purpose is key in composing a thesis statement, in that it directs the writer not to lose focus in phrasing his statement for the thesis. Hence, the thesis itself which emanates from the statement of purpose should provide a direction for the entire paper. For example, the possible thesis statement 1 - The music of Daddy Lumba has been heavily influenced by the 21st century youth in Ghana - can set the stage for intense discourse analysis between lovers of "Kwadjo Antwi's*" music and that of "Daddy Lumba" or between people who agree to the assertion and people who do not. Again, in possible thesis statement 2, not everybody in Ghana will accept the idea that the "Azonto Dance" has heavily influenced Ghanaians. Of course, there are people in Ghana who are opposed to this new dance. Also, we have Ghanaians who cherish some traditional dances like: Adowa, Kete, Palongo, Bamaya, Kple and Agbadza much more than they cherish a new dance like: Azonto. Accordingly, this makes the thesis statement a controversial one. Also, in possible thesis statement 4, most opponents of Barcelona Football Club, especially the supporters of Real Madrid - who see Cristiano Ronaldo as the best player in the world - will not concur to the declaration that Lionel Messi is the most skilful player on earth. This is also another way of writing a strong thesis statement.

Johnson (2004) also argues that for the thesis statement to be interesting, it should be arguable and specific. It should have the ability of generating the interest of others so that they could look at the idea(s) being expressed from a different viewpoint. Tagg (2004) also opines that it should be controversial and defensible. For this to happen, the writer should ask himself whether it would be possible to argue the thesis from the opposite way; if not, then it is not a thesis - it is more of a fact (Johnson, 2004). We cite the following instances to explain Johnson's (2004) point:

- Not Arguable: Mobile phones are becoming an efficient mechanism for transmitting oral information across the world.

- Arguable: Intense use of mobile phones may disturb family unity and increase cases of divorce in our society.

Taking a closer look at the two statements, it is noticeable that while the first (not arguable) is a statement of fact, the second (arguable) is a statement which is debatable. Many people will find it difficult to believe that intense use of mobile phones may disturb family unity and increase cases of divorce in our society. This is a good thesis, since it could set the stage for a "hot" debate.

Specificity is also a vital ingredient in writing an appealing thesis. The thesis should contain detail and specificity (Johnson, 2004). Providing detail and being explicit helps in doing away with vague, general and sweeping statements. It is therefore imperative that the thesis should always be substantiated by detailed information. Detailed information makes the thesis clear and unambiguous (Tagg, 2004). And if a statement is clear and unambiguous, then it means it has not been stated in such a way to mean different things to different people. We provide the following example to illustrate our point on poor and good specificity:

- Poor Specificity: "We should not investigate the causes of the Baba Yara Sports Stadium ${ }^{3}$ blackout when Ghana played Lesotho on June 1, 2012."

- Good Specificity: "Because the blackout incident that occurred in the Baba Yara Sports Stadium, when Ghana played Lesotho on June 1, 2012 could have serious repercussions on the nation's sporting activities, the blackout should be investigated.

In the first example (poor specificity) the writer does not provide details as to why the blackout should not be investigated. Hence, this statement does not provide any logic for the reader. But the second example (good specificity) does provide details as to why the blackout should be investigated; and this makes the thesis logical enough.

One other method that can be used in writing a captivating thesis is to follow an "although ... actually" format (Johnson, 2004). The "although ... actually" format is one of the most effective ways of finding something original and controversial to say (Johnson, 2004). In using this format, one tries to convince one's readers that what they thought to be previously true really is not. This statement always has two clauses - the main clause and the subordinate. Examples are illustrated below:

- Example 1: Although Ghana Black Stars ${ }^{4}$ won 7 goals to 0 against the Crocodiles of Lesotho ${ }^{5}$ on June 1, 2012, actually they should not be complacent as this could mar their progress in the FIFA qualifying matches for Brazil 2014.

\footnotetext{
${ }^{1}$ Daddy Lumba and Kwadjo Antwi and two of the most celebrated highlife musicians in Ghana.

${ }^{2}$ The "Azonto Dance" is one of the popular and most recent dances in Ghana.

${ }^{3}$ Baba Yara Sports Stadium, Kumasi, is one of the well resourced sports stadia in Ghana.

${ }^{4}$ Ghana Black Stars, is the official name of the senior football team of Ghana.
} 
- Example 2: Although a PhD is now a prerequisite for getting on board most research institutions as a lecturer (actually) it does not ensure one's promotion.

It is important to note that the adverb actually can be deleted without the meaning of the statement being affected. The two examples, which are both strong thesis statements, are controversial and can be subjected to strong debate. However, this does not mean that a good thesis statement must almost always be controversial. An example is: my husband and I have several effective ways of disciplining our children (Langan, 2001, p.52). When the thesis and its supporting details have been well composed, the essayist is now ready to write the body of the composition in the form of varying paragraphs.

\section{Methodology OF THE ReSEARCH}

\section{A. Research Design}

The research design employed for this work is qualitative and descriptive. The two tools are selected for the work because of their proclivity to providing descriptions of phenomena that occur naturally (Seliger and Shohamy, 2001, p.116). In using qualitative and descriptive tools, attention was given to only the thesis statement of each essay. That is to say the grammar of students' composition and the whole structures of the essays of the participants were not the main focus of this study. The reason is that grammar and the structure of an essay are broad areas which would require a different research work to focus on.

\section{B. Data, Sample and Sampling Technique}

Data and the methods used in collecting them are crucial to the success of every investigative study. The data were obtained from 30 texts or scripts composed by participants. The participants were drawn from students in the business departments of two prominent private universities (Christian Service University College and Ghana Baptist University College) in Kumasi, Ghana. To be gender balanced, 50\% males (15participants) and 50\% females (15participants) were randomly selected out of 100 students who wrote essays on various topics. These essays were written as part of the assessment on essay writing lecture sessions. They were made to compose essays on five methods of development narrative, cause and effect, descriptive, comparison and contrast, and argumentative. The table below is the break-down of the topic under each method of development and the number of participants who wrote them:

TABLE 2:

ESSAY TOPICS AND THE NUMBER OF PARTICIPANTS WHO WROTE THEM

\begin{tabular}{|lll|}
\hline $\begin{array}{l}\text { TOPICS ON THE METHODS OF } \\
\text { DEVELOPMENT }\end{array}$ & $\begin{array}{l}\text { NUMBER OF } \\
\text { PARTICIPANTS }\end{array}$ & $\begin{array}{l}\text { PERCENTAGE } \\
(\boldsymbol{\%})\end{array}$ \\
\hline $\begin{array}{l}\text { CAUSE AND EFFECT: Discuss the Causes and } \\
\text { Effects of Divorce }\end{array}$ & 6 (3 males and 3 females) & $\mathbf{2 0}$ \\
\hline $\begin{array}{l}\text { NARRATIVE: Narrate a story that begins with } \\
\text { the statement: "Riding a motorbike has always } \\
\text { been my hobby; but one day, I learnt a bitter } \\
\text { lesson" }\end{array}$ & 6 (3 males and 3 females) & $\mathbf{2 0}$ \\
\hline $\begin{array}{l}\text { DESCRIPTIVE: Describe a political rally you } \\
\text { recently attended. }\end{array}$ & 6 (3 males and 3 females) & $\mathbf{2 0}$ \\
\hline $\begin{array}{l}\text { COMPARISON AND CONTRAST: Compare } \\
\text { and contrast life in rural and urban areas }\end{array}$ & 6 (3 males and 3 females) & $\mathbf{2 0}$ \\
\hline $\begin{array}{l}\text { ARGUMENTATIVE: Write your speech for or } \\
\text { against the motion "scientific Advancement is a }\end{array}$ & 6 (3 males and 3 females) & $\mathbf{2 0}$ \\
\hline $\begin{array}{l}\text { Curse to Mankind" } \\
\text { TOTAL }\end{array}$ & $\mathbf{3 0}$ & $\mathbf{1 0 0}$ \\
\hline
\end{tabular}

\section{DisCUSSION OF RESUlTS}

The study revealed that most students in the business departments of private universities find it problematic including a thesis statement in their compositions. Thus, all the essays given to students required that a thesis be included in the introduction; but out of 30 scripts analysed, only 4 (texts 6, 9, 24 and 30) representing 13\% have thesis statements; while the remaining $87 \%$ did not have. This is illustrated in table 3 below:

TABLE 3:

THESIS STATEMENTS IN STUDENTS' ESSAYS

\begin{tabular}{|lll|}
\hline $\begin{array}{l}\text { THESIS STATEMENTS IN PARTICIPANTS' } \\
\text { ESSAYS }\end{array}$ & $\begin{array}{l}\text { NUMBER } \\
\text { OF TEXTS }\end{array}$ & $\begin{array}{l}\text { PERCENTAG } \\
\text { E (\%) }\end{array}$ \\
\hline Essays with Thesis Statements & 4 & 13 \\
\hline Essays without Thesis Statements & 26 & 87 \\
\hline TOTAL & $\mathbf{3 0}$ & $\mathbf{1 0 0}$ \\
\hline
\end{tabular}

\footnotetext{
${ }^{5}$ Crocodiles is the official name of the senior football team of Lesotho.
} 


\section{A. Discussion on Essays without Thesis Statements}

As already stated, $87 \%$ (26) of the participants did not include a thesis in their texts. The reasons are as follows: one, most of the texts did not have introductions at all (for example, texts 15, 16, and 25). The participants wrote on the topics given straight away within introducing them to their readers. Obviously, that explains the basis for missing theses. This, therefore, made their essays monotonous. Again, although the remaining 23 texts out of the 26 had various introductions, the theses were speciously couched. For example, in text 1, where the participants wrote on the causes and effects of divorce, the only statement in the introduction is the sentence: There are causes and effects of divorce which destroy marriages in our societies. Clearly, this statement is not in consonance with Johnson's (2004) assertion on thesis statement that says that for a thesis statement to be effective, it must be arguable and specific.

Another example was seen in text 29, where the participant wrote a descriptive essay. The only statement in the introduction - One hot Sunday morning, my friends and I hurried to the Market Square to witness a political rally by a political party called the National People Party - cannot serve as the thesis. It is a statement of fact. Thus, Felts (2006) thinks that a thesis is not a fact, but an assertion about facts. Moreover, the statement announces the subject matter of the essay - political party - rather than state a true thesis idea. This according to Langan (2001, p.53), is a mistake. Several reasons might have resulted in the production of these errors:

One, most language lecturers who teach in the business departments of private universities focus more attention on business write-ups topics such as reports, minutes, memorandum, business letters, application letters, and proposals than they focus on a topic like essay writing which requires the study of thesis statements. Perhaps, this is because the business student would write more business correspondence at the work place. Another problem is that some course outlines of English language related subjects of the business departments of most private universities do not capture thesis statement writing. Because of this situation, most English language lecturers sometimes do not treat areas such as the various methods of development, and the entirety of paragraph theory which will require the business student to write thesis statements. Again, an obvious problem to students' poor writing skills on thesis statements is lack of effective assessment in terms of essay writing (which will expose students' ability or inability of including thesis statements in their essays). At the business departments of private universities in Ghana, English language courses (i.e. Business Communication, Communication Skills I and II, English language I and II, etc) are mostly done in levels 100 and 200 (that is first and second years), where we have hundreds of students who do general courses before they focus on their area of specialisation at levels 300 and 400 (that is third and fourth years). Because of the large number of students at these levels, a good number of language lecturers in the business departments of most private universities set about $80 \%$ multiple choice questions and short answer-type questions and $20 \%$ of essay-type questions for both continuous assessment and end of semester examinations for fear that they might not be in a position to meet the deadline set by Examinations Officers if they are to mark more essay-type questions. So, the student goes through the university system without knowing his or her writing flaws on thesis statement; and these uncorrected writing errors on thesis statement remain with them as they enter their professional lives. Availability and adequacy of the required lecture materials on writing skills (especially on the writing of thesis statement) is also another problem for the majority of students who study in the business departments of privately-owned universities. To a large extent the student in stateowned universities such as Kwame Nkrumah University of Science and Technology and University of Ghana has access to diverse literature on the study of thesis statement from their well established and resourced libraries. But, the student in the business departments of most private universities such as Ghana Baptist and Christian Service University Colleges goes through writing skills without getting the right study materials on thesis statements; even if the materials are available, they are not enough for hundreds of students who pursue English and English related course at levels 100 and 200. Thus, the students do not have any other option than to rely on the lecture material(s) given to them by their lecturers. Another issue is that, most of these lecture notes/materials given by lecturers are synopses of the various topics treated in class. So, in a situation where the student uses the lecture notes as the only reference material, he or she finds it difficult to comprehend the complex issues (especially on thesis statements) which were not exhaustively treated in class.

\section{B. Discussion on Essays with Thesis Statements}

As already indicated only $4(13 \%)$ of the participants' texts had thesis statements. The thesis statement in text $6-$ Divorce is a painful experience. Though no one wishes for it, most of the times it happens to most married couples - for example, is not broad and has not been worded in the negative sense. This is in consonance with the assertion of Tagg (2004) that the negator - not - should be absent in the construction of a thesis statement. Again, although, the idea behind the participant's thesis statement is true, it is arguable in that it is not everyone who will agree that divorce is a painful experience. For instance, if one person within a marriage were abused and suppressed, he or she would not see divorce as a painful experience, but an opportunity to perhaps be liberated from painful situations. This makes the thesis statement an effective one.

Moreover, the thesis statement of text 30 - In this world of power struggle, politics has taken a centre stage in all human endeavours making it very hard to ignore even if you are not a fan of it - is debatable; because while some people will believe it in its entirety, there are others in society who will not agree that politics has taken a centre stage in all human endeavours since they might not be interested in politics and they would therefore not encourage it in their 
domain. Again, this thesis is not a statement of fact; and that makes it more acceptable. Felts (2006) has put forward that a good thesis is not a factual statement, but is an assertion about facts.

\section{CONCLUSION}

This work has looked at only the construction of thesis statements in students' expository essays. More research is therefore needed in other areas such as the grammar, and the sentence construction in students' expository essays. Looking at the data collected from the field and the discussion of results, one realizes that most students, indeed, find it difficult constructing a thesis statement. It is therefore recommended that language teachers and lecturers should devote amply time in teaching students this theory. It is also recommended that the course outlines for Business Communication and Communication Skills of business schools of private universities in Ghana should have a separate section for thesis statement writing.

\section{REFERENCES}

[1] Abrams, E. (2000). Essay Structure. <www.fas.harvard.edu> 18 February 2012.

[2] Carroll, Armstrong Joyce; Wilson, E. Edward; and Forlini, Gary. (2001). Writing and Grammar:Communication in Action, Bronze Level. New Jersey: Prentice-Hall Inc.

[3] Felts, D. (2006). Developing Clear Thesis Statements. <www.uhv.edu/ac>18 February 2012.

[4] Forlini, Gary; Bauer, Mary Beth; Biener, Lawrence; Capo, Linda; Kenyon, Karen Moore; Shaw, Darla H.; and Verner, Zenobia (1987). Grammar and Composition, 3rd Edition. New Jersey: Prentice-Hall, Inc.; Englewood Cliffs.

[5] Hoy II, Pat C. (1992). Reading and Writing Essays: The Imaginative Tasks. U.S.A: McGraw-Hill, Inc.

[6] Jerz, D. G. (2011). Thesis Statements: How to Write them in Academic Essays. <www.jerz.setonhill.edu/.../thesis-statementwriting-academic-essays> 18 February 2012.

[7] Johnson, T. (2004). Ten Steps to Writing an Essay. <www.aucegypt.edu/academic/writers> 29 January 2012.

[8] Lane, S. (2004). How to Write a Good Essay. <www.classbrain.com>18 February 2012.

[9] Langan, J. (2001). College Writing Skills with Readings, Fifth Edition. New York: McGraw-Hill Companies Inc.

[10] Samuels, H. (2004). Writing a Thesis Statement. <www.crlsresearchguide.org/13_thesis_statement> 24 February 2012.

[11] Seliger, H. W. and Shohamy, E. (2001). Second Language Research. Oxford: Oxford University Press.

[12] Tagg, J. (2004). Discovering Ideas Handbook: The Thesis Statement. <www.daphne.palomar.edu/handbook/thesis.hitm> 18 February 2012.

[13] <www.leo.stcloudstate.edu> 13 February 2012.

Edward Owusu holds an MBA in Human Resource Management from the Kwame Nkrumah University of Science and Technology Kumasi, Ghana; an MA and an MPhil in Teaching English as a Second Language from the University of Ghana, Legon, Accra. He is a faculty member in the Department of Liberal and General Studies, Sunyani Polytechnic, Sunyani, Ghana. His recent book - Modern Business Communication - was published in 2012.

Asuamah Adade-Yeboah holds an MA in Comparative Literature from the Kwame Nkrumah University of Science and Technology, Kumasi, Ghana. He is a lecturer in the Department of Communication Studies, Christian Service University College, Kumasi, Ghana. He has three publications in other international peer-reviewed Journals. His recent book -Practical English for Effective Communication - was published in 2008. At the moment, he is a P. hD candidate in Univeridad Empresarial de Costa Rica (UNEM). 